О.С. Токар, А.М. Козел, М.М. Король, А.М. Цуняк

МЕТОДИ ОТРИМАННЯ ПАРАМЕТРІВ МАТЕМАТИЧНИХ МОДЕЛЕЙ

ДИНАМІКИ ДЕРЕВОСТАНІВ

О.Ю. Федевич

АНАЛІЗАТОР ПРОТОКОЛІВ КОМП'ЮТЕРНОЇ МЕРЕЖІ ДЛЯ

ОПТИМІЗАЦІЇ АДАПТИВНОГО УПРАВЛІННЯ ТРАФІКОМ ПОТОКУ .............374

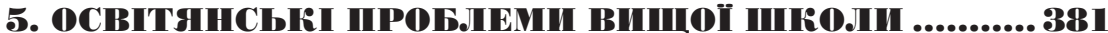

T.М. Білущак

ДОСЛІДЖЕННЯ СОЦІАЛЬНО-ПСИХОЛОГІЧНОГО КЛІМАТУ ТА

МОТИВАЦІЇ ВИКЛАДАЦЬКОГО КОЛЕКТИВУ ЯК ЧИННИКИ УСПІХУ

ОСВІТНЬОГО МЕНЕДЖМЕНТУ.

\section{М.В. Одрехівський}

МЕТОДОЛОГІЧНІ ПІДХОДИ ДО УПРАВЛІННЯ ПІДПРИЄМНИЦЬКИМИ

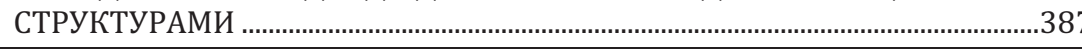

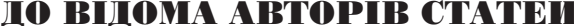

\section{1. ЛICDВE TA САДОВD-ПАРКОВЕ ГОСПОДАРСТВО}

\section{УДК 630.232.32}

ПОКАЗНИКИ РОСТУ СОСНОВИХ КУЛЬТУР, СТВОРЕНИХ САДИВНИМ МАТЕРІАЛОМ ІЗ ЗАКРИТОЮ КОРЕНЕВОЮ СИСТЕМОЮ

\author{
О.Ю. Андреєва ${ }^{1}$, А.І. Гузій ${ }^{2}$ Р.А. Карчевський
}

Здійснено порівняння показників росту культур сосни звичайної, створених садивним матеріалом із закритою та відкритою кореневими системами, у перші роки вирощування. Доведено, що діаметр кореневої шийки, висота і приріст за висотою достовірно більші в соснових культурах, створених садивним матеріалом із закритою кореневою системою, ніж відповідні показники у культурах, створених садивним матеріалом із відкритою кореневою системою. Спосіб вирощування садивного матеріалу впливає на ріст культур переважно у перші роки, а згодом переважну роль у рості відіграють екологічні умови. Достовірно більші значення ширини крони уздовж та впоперек рядів трирічних і чотирирічних культур, створених садивним матеріалом із закритою кореневою системою, порівняно 3 варіантами використання садивного матеріалу 3 відкритою кореневою системою, свідчать, що використання садивного матеріалу із закритою кореневою системою може пришвидшити терміни змикання культур.

Ключові слова: сосна звичайна, лісові культури, садивний матеріал із закритою кореневою системою, показники росту, ширина крони

Вступ. Нині, в умовах змін клімату, зростання антропогенного навантаження [1], загальної тенденції до погіршення стану соснових лісів і зростання ризику ушкодження природного та штучного поновлення комахами та хворобами [8], зростає нагальна потреба вдосконалення технологій вирощування садивного матеріалу та створення стійких лісових культур. Так, у п'яти лісових господарствах Новгород-Сіверського Полісся із створених за 18 років переведено до вкритих лісовою рослинністю земель за першим, другим і третім класами якості 21,8; 47,8 та 30,4 \% площі культур [2].

Одним із шляхів покращення стану лісових культур є використання садивного матеріалу лісових порід із закритою кореневою системою [3, 7]. Порівняно з використанням сіянців, вирощених за традиційною технологією у розсаднику чи теплиці, вирощування садивного матеріалу із закритою кореневою системою забезпечує зменшення травмування рослин під час транспортування й висаджування у культурах, уразливості кореневих систем до пошкодження комахами, надає можливість подовження періоду створення лісових культур, полегшення дозованого застосування добрив і регуляторів росту [6]. Незважаючи на доволі тривалий час вирощування садивного матеріалу із закритою кореневою системою у різних регіонах, зазначені вище переваги не завжди вияв-

' доц. О.Ю. Андреєва, канд. с.-г. наук - Житомирський національний агроекологічний університег; 2 проф. А.І. Гузій, д-р с.-г. наук - Житомирський національний агроекологічннй університет 3 директор Р.А. Карчевський - ДП "Житомирське лісове господарство"

1. Лісове та садово-паркове господарство 
ляються, що залежить значною мірою від технології вирощування садивного матеріалу та культур із його використанням [3, 5].

Метою роботи - порівняння показників росту культур сосни звичайної (Pinus sylvestris L.), створених садивним матеріалом із закритою та відкритою кореневими системами, у перші роки вирощування.

Матеріали та методи. Садивний матеріал сосни звичайної вирощено у Базовому розсаднику ДП "Житомирське ЛГ" з попередньо підготовленого елітного насіння 2-го класу, сіянці з відкритою кореневою системою - за загальноприйнятою технологією. Садивний матеріал із закритою кореневою системою вирощували у весняно-літніх теплицях у контейнерах місткістю 250-300 $\mathrm{cm}^{3}$, наповнених грунтовим субстратом і вміщених у дерев'яні короби $(2 \times 4$ м), дно яких утворює - металева сітка. Дно коробів покривали агроволокном.

Для формування субстрату в теплицях застосовували грунтову масу зв'язно-піщаного або супіщаного гранулометричного складу, отриману змішуванням торфу фрезерного з піском річковим і грунтом лісовим. Грунт відбирали з добре гумусованих шарів під наметом лісових насаджень в умовах свіжих суборів або сугрудів. Просіяну грунтову масу завозили восени. Готовою сумішшю вручну наповнювали поліетиленові контейнери діаметром $5 \mathrm{~cm}$ і заввишки 10 см, які нарізали з поліетиленових рукавів.

Контейнери формували у період із жовтня по лютий. Насіння висівали наприкінці лютого або на початку березня з розрахунку 3-4 насінини на один контейнер. Сіянці щомісяця протруювали фунгіцидами (актара, превикур), підгодовували новофертом кожні 10-14 днів. Регулярний полив забезпечували системою "туман". Садіння культур здійснювали ручним способом під меч Колесова, обробіток грунту - борознами. Кореневі системи сіянців, вирощених із відкритою кореневою системою, перед садінням вмочували у глиняно-перегнійну бовтанку. Загалом за 2012-2014 pр. створено 17,6 га культур з використанням садивного матеріалу сосни звичайної із закритою кореневою системою.

Для детального вивчення відібрано ділянки культур, створених у свіжому субору на зрубах суцільної санітарної рубки у 2012, 2013 і 2014 рр., причому для кожної ділянки культур, створених садивним матеріалом із закритою кореневою системою, підбирали ділянку культур, створених садивним матеріалом із відкритою кореневою системою у подібних умовах і в той самий рік. За схемою змішування аналізовані культури 2012 та 2013 рр. створення (4-річні) містили на кожні 4 ряди сосни звичайної 1 ряд дуба звичайного чи модрини європейської, а культури 2014 р. створення були чистими сосновими.

У 2015 р. на дослідних ділянках було виміряно діаметр кореневої шийки, висоту рослин, прирости у висоту за 2012, 2013, 2014 і 2015 pp., а також ширину крони у напрямках уздовж та впоперек ряду. Дані згруповано за роками та піддано статистичному аналізу загальноприйнятими методами [4] за допомогою пакету програм MS Excel. Для аналізу зв'язку приросту культур у висоту з погодними умовами використано дані метеостанції Житомир за 2012-2015 pp.

Результати та обговорення. Діаметр кореневої шийки саджанців, створених садивним матеріалом із закритою кореневою системою, був більшим, ніж $\overline{10}$ цей показник саджанців, створених садивним матеріалом із відкритою кореневою системою (рис. 1).

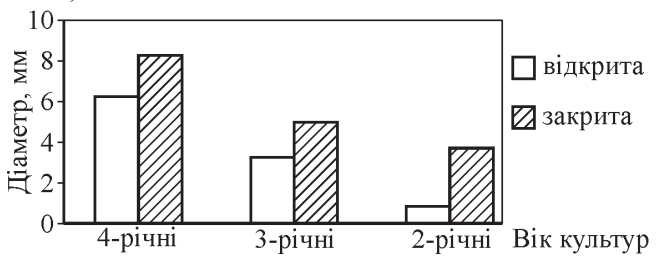

Рис. 1. Діаметр кореневоі иийки саджанців сосни у культурах, створених садивним матеріалом із відкритою та закритою кореневими системами

Різниці статистично підтверджені для всіх досліджених культур $\left(t_{0,001}=3,3 ; t_{\text {факт. }}-11,8 ; 8,2\right.$ та 5,7 стосовно 2-річних, 3-річних і 4-річних культур відповідно). Найбільше перевищення діаметра кореневої шийки саджанців у дворічних культурах (на 343 \%) пов'язане з тим, що садивний матеріал, вирощений у контейнерах, ще на момент садіння мав більший діаметр, аніж вирощений із відкритою кореневою системою. Перевищення діаметра кореневої шийки саджанців у трирічних і чотирирічних культурах становило 53,2 та 32 \% відповідно, тому що на ріст культур впливали умови навколишнього середовища.

Коефіцієнт варіювання діаметра саджанців із відкритою кореневою системою виявився майже вдвічі більшим, ніж саджанців із закритою кореневою системою (41,8-45,5 \% та 21,6-28 \% відповідно). Висота саджанців, створених садивним матеріалом із закритою кореневою системою, була більшою, ніж цей показник саджанців, створених садивним матеріалом із відкритою кореневою системою (рис. 2). Різниці статистично підтверджені для всіх досліджених культур $\left(t_{0,001}=3,3 ; t_{\text {факт. }}-15,3 ; 10,2\right.$ та 3,6 стосовно 2-річних, 3 -річних і 4-річних культур відповідно). Висота дворічних культур, створених садивним матеріалом із закритою кореневою системою, перевищувала висоту культур, створених садивним матеріалом із відкритою кореневою системою, на 87,6\%, а трирічних і чотирирічних культур - на 45,2 та 15,5 \% відповідно.

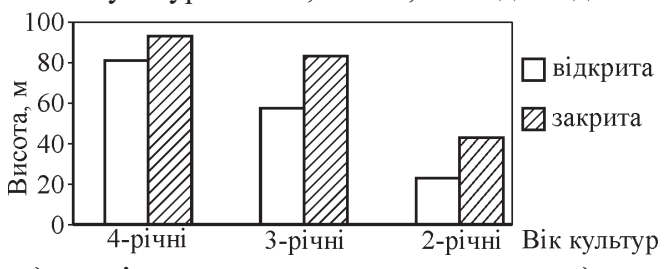

Рис. 2. Висот саджанців сосни у культурах, створених садивним матеріалом із відкритою та закритою кореневими системами

Коефіцієнт варіювання висоти саджанців із відкритою кореневою системою також був більшим, ніж саджанців із закритою кореневою системою (30,233,3 \% та 16,8-22,7 \% відповідно). Коефіцієнт варіювання приросту за висотою саджанців із відкритою кореневою системою у 2015 р. також був більшим, ніж саджанців із закритою кореневою системою $(39,0-48,1 \%$ та 24,0-32,2 \% відповідно). Водночас, приріст за висотою у 2015 р. саджанців, створених садивним 
матеріалом із закритою кореневою системою, лише у дво- і трирічних культурах був більшим, ніж цей показник саджанців, створених садивним матеріалом із відкритою кореневою системою (рис. 3). За даними статистичного аналізу, $t_{\text {факт. }}-10,6 ; 3,2$ та 0,23 стосовно дворічних, трирічних і чотирирічних культур відповідно $\left(t_{0,01}=2,6 ; t_{0,05}=1,97\right)$. Приріст за висотою дворічних культур, створених садивним матеріалом із закритою кореневою системою, перевищував приріст культур, створених садивним матеріалом із відкритою кореневою системою, на 59,5 \%, а трирічних і чотирирічних культур - на 22 та 1,3 \% відповідно.

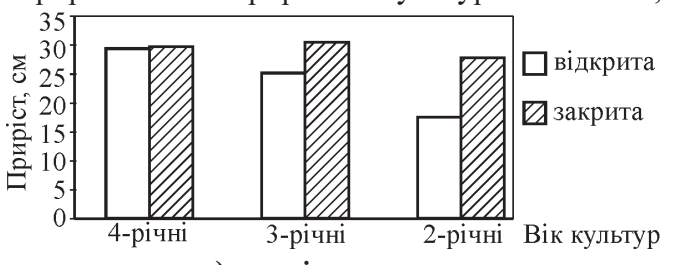

Рис. 3. Приріст за висотою саджанців сосни у культурах, створених садивним матеріалом із відкритою та закритою кореневими системами

Отримані дані (див. рис. 1-3) свідчать, що спосіб вирощування садивного матеріалу впливає на ріст культур переважно у перші роки, а згодом переважну роль у рості відіграють екологічні умови. Було зіставлено дані стосовно приросту за висотою трирічних і чотирирічних культур сосни, створених садивним матеріалом із відкритою та закритою кореневими системами, та кількість опадів у травні-червні (рис. 4). Так, за даними метеостанції Житомир, середня багаторічна кількість опадів у травні та червні становить 64,1 і 78,9 мм відповідно, а разом - 143 мм.

У період, за який аналізували приріст культур за висотою, кількість опадів за цей період поступалася середнім значенням у 2012 (на 6,3 \%), 2013 (на $9,1 \%$ ) і 2015 pp. (на 31,5 \%), і лише у 2014 р. перевищувала їх на 20,3\%. Саме у 2014 р. приріст культур за висотою у більшості варіантів різко зростає, причому стосовно варіантів використання садивного матеріалу із закритою кореневою системою це зростання виражене більшою мірою як у трирічних, так і у чотирирічних культурах. Під час вирощування культур дуже важливим є забезпечення найшвидшого змикання у рядах і у міжряддях. Одним із показників, за яким можна прогнозувати терміни такого змикання, $є$ ширина крони.

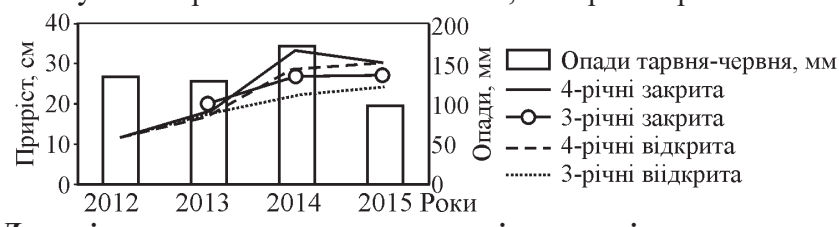

Рис. 4. Динаміка приросту за висотою три- $i$ чотирирічн их соснових культур, створен их із відкритою та закритою кореневими системами, та кількості опадів у травні-червні

Аналіз даних, наведених на рис. 5, свідчить, що ширина крони трирічних і чотирирічних саджанців сосни уздовж і впоперек ряду була достовірно більшою у варіантах використання садивного матеріалу із закритою кореневою системою.

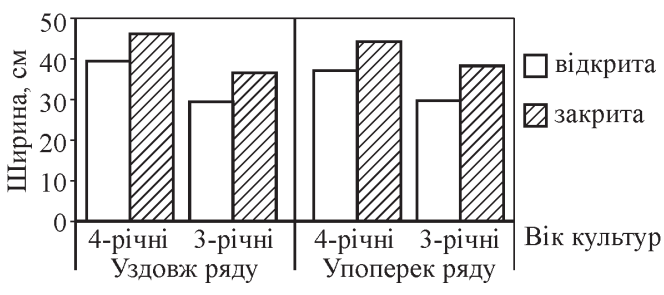

Рис. 5. Ширина крони саджанців сосни у культурах, створених садивним матеріалом із відкритою та закритою кореневими системами

Значення критерію Ст'юдента під час порівняння ширини крони уздовж ряду чотирирічних і трирічних культур становлять 3,5 і 4,3 відповідно, а ширини крони впоперек рядів - 3,8 і 4,6 відповідно $\left(t_{0,01}=2,6 ; t_{0,001}=3,3\right)$. Ширина крони уздовж ряду у трирічних і чотирирічних культурах, створених садивним матеріалом із закритою кореневою системою, перевищувала цей показник у варіантах використання садивного матеріалу з відкритою кореневою системою на 24,5 і $17,3 \%$, а ширина крони впоперек ряду - на 29,7 і 21,3 \% відповідно. Отримані дані свідчать, що використання садивного матеріалу із закритою кореневою системою може пришвидшити терміни змикання культур.

\section{Висновки:}

1. Діаметр кореневої шийки, висота та приріст за висотою достовірно більші у соснових культурах, створених садивним матеріалом із закритою кореневою системою, ніж відповідні показники у культурах, створених садивним матеріалом із відкритою кореневою системою.

2. Варіювання показників діаметра кореневої шийки, висоти та приросту за висотою $€$ більшим у культурах, створених садивним матеріалом із відкритою кореневою системою.

3. Різниці значень усіх показників у відсотках у варіантах використання садивного матеріалу із відкритою та закритою кореневими системами та їхня достовірність зменшуються у міру збільшення віку культур.

4. Приріст культур за висотою у більшості варіантів різко зростає у 2014 р., коли кількість опадів у травні-червні перевишила багаторічні значення на $20,3 \%$, причому це зростання виражене більшою мірою у варіантах використання садивного матеріалу із закритою кореневою системою.

5. Ширина крони уздовж ряду у трирічних і чотирирічних культурах, створених садивним матеріалом із закритою кореневою системою, перевищувала цей показник у варіантах використання садивного матеріалу з відкритою кореневою системою на 24,5 і $17,3 \%$, а ширина крони впоперек ряду - на 29,7 і 21,3 \% відповідно. Це свідчить, що використання садивного матеріалу із закритою кореневою системою може пришвидшити терміни змикання культур.

\section{Література}

1. Ворон В.П. Ліси зеленої зони м. Рівне та їх еколого-захисні функції / В.П. Ворон, С.В. Івашинюта, І.М. Коваль, М.А. Бондарук. - Харків : Вид-во "Нове слово", 2008. - 224 с.

2. Дем'яненко Л.В. Стан лісових культур та перспективи природного поновлення лісів в умовах Новгород-Сіверського Полісся / Л.В. Дем'яненко // Лісівництво і агролісомеліорація : зб. наук. праць. - Харків : Вид-во УкрНДІЛГА ім. Г.М. Висоцького. - 2015. - Вип. 126. - С. 165-172.

1. Лісове та садово-паркове господарство 
3. Жигунов А.В. Теория и практика выращивания посадочного материала с закрытой корневой системой / А.В. Жигунов. - СПб. : Изд-во СПбНИИЛХ, 2000. - 293 с.

4. Лакин Г.Ф. Биометрия : учеб. пособ. [для студ. биол. спец. ВУЗов] / Г.Ф. Лакин. - М. Изд-во "Высш. шк.", 1990. - 352 с

5. Лялін О.І. Агротехніка вирощування сіянців дуба звичайного з закритою кореневою системою / О.І. Лялін // Вісник ХНАУ : зб. наук. праць. - Сер.: Ірунтознавство, агрохімія, землеробство, лісове господарство, екологія. - Харків : Вид-во ХНАУ. - 2009. - Вип. 4. - С. 109-111.

6. Лялін О.І. Стан і ріст соснових культур, створених садивним матеріалом із закритою кореневою системою / О.І. Лялін // Лісівництво і агролісомеліорація : зб. наук. праць. - Харків Вид-во УкрНДІЛГА ім. Г.М. Висоцького. - 2008. - Вип. 113. - С. 93-100.

7. Zhigunov A. Establishment of forest plantations with container tree seedlings / A. Zhigunov, T. Saksa, J. Sved // St. Petersburg, Suonenjoki: St. Petersburg Forest Technical University, Finnish Forest Research Institute. - 2014. - 44 p.

8. Meshkova V. Foliage browsing insects outbreaks in Ukraine before and after global warming V. Meshkova, K. Davydenko // Delb, H., Pontuali, S.(eds.): Biotic Risks and Climate Change in Forests. Proceedings of the Working Party 7.03.10 Methodology of Forest Insect and Disease Survey in Central Europe, 10th Workshop September 20th-23rd, 2010, Freiburg, Germany. Berichte Freiburger Forstliche Forschung. - 2011. - Heft 89, FVA. - Pp. 18-25.

Надійшла до редакції 28.03.2016 p.

Андреева Е.Ю., Гузий А.И., Карчевский Р.А. Показатели роста сосновых культур, созданных посадочным материалом с закрытой корневой системой

Проведено сравнение показателей роста культур сосны обыкновенной, созданных посадочным материалом с закрытой и открытой корневыми системами, в первые годы выращивания. Доказано, что диаметр корневой шейки, высота и прирост по высоте достоверно больше в сосновых культурах, созданных посадочным материалом с закрытой корневой системой, чем соответствуюшие показатели в культурах, созданных посадочным май истелом с опкрытой корневой снстемой. Способ вьрачнвания посадонного ма-

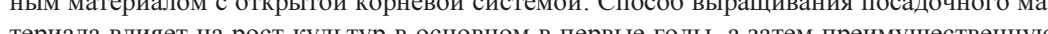

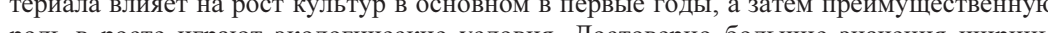
роль в росте играот эколон кроны вдоль и поперек рядов трехлетних и четырехлетних культур, созданных посадочным материалом с закрытой корневой системой, в сравнении с вариантами использования посадочного материала с открытой корневой системой, свидетельствуют о том, что использование посадочного материала с закрытой корневой системой может ускорить сроки смыкания культур.

Ключевые слова: сосна обыкновенная, лесные культуры, посадочный материал с закрытой корневой системой, показатели роста, ширина кроны.

Andreeva O.Yu., Huzii A.I., Karchevskyi R.A. Some Parameters of Pine

\section{Growth in Plantations Created with Potted Planting Material}

Comparison of growth parameters in pine plantations created with planting material with closed and open root system was carried out in the first years of growing. It is proved that root collar diameter, height and height growth was significantly greater in pine plantations created with potted planting material, than with open root system. The method of ons con planting mal cocological conditions play the darger crown widh along and acter planting material, in comparison with variants using planting material with open root system Ke Keywords: Scotch pine, forest plantations, potted planting material, parameters of growth, crown width.
УДК 630*266

\section{ЗАХИСНЕ ЛІСОРОЗВЕДЕННЯ В АГРОЛАНДШАФТАХ ЗІВДЕННО-СХІДНО ЧАСТИНИ БАЙРАЧНОГО}

Ю.М. Біла ${ }^{1}$, Л.І. Ткач ${ }^{2}$

Досліджено сучасний рівень лісомеліоративного захисту аграрних угідь регіону $\mathrm{i}$ запропоновано сучасні підходи щодо забезпечення ефективного захисту земель за допомогою систем захисних насаджень. Потрібну кількість захисних лісових насаджень розраховують на регіональному рівні шляхом урахування місцевих природних та антропогенних проблем, що негативно впливають на сільськогосподарське виробництво. Важливими для удосконалення просторової структури сучасних агролісоландшафтів $\epsilon$ запропоновані прогнозні обсяги захисних лісових насаджень різних просторово-цільових форм, які грунтуються на сучасній нормативній базі. Їх можна використати для планування оптимальних з агроекологічної точки зору зональних агроландшафтів та забезпечення стабільного сільськогосподарського виробництва, економічної доцільності господарювання і створення належних соціальних умов,

Ключові слова: агроландшафт, несприятливі природні явища, захисні лісові насадження, нормативи захисної лісистості.

Вступ. Природні умови південно-східної частини північного (байрачного) степу відзначаються низкою несприятливих для ведення сільського господарства явищ [1] та ця територія піддається надмірному техногенному навантаженню, особливо за останні роки. Тому дедалі частіше спостерігаються екстремальні прояви клімату, які завдають значних збитків землеробству [2]. Це вимагає застосування сучасних методів захисту агроландшафтів, насамперед заходами постійної дії, серед яких чільне місце належить полезахисному лісорозведенню. Щоб уникнути подальшого збільшення площ деградованих та малопродуктивних грунтів, особливо від посушливих явищ та ерозії грунтів, потрібно розробити і впровадити на орних землях ефективні системи полезахисних насаджень переважно лінійного типу.

Водночас, розроблені нові нормативи [3] та правила, які забезпечують формування стійких, екологічно збалансованих агроландшафтів та методологія адаптивно-ландшафтної лісомеліорації $[4,5]$, які унеможливлюють та нівелюють зазначені негаразди. Станом на 01.01.2013 р. за інформацією Держземагентсва України обліковано на території Луганської обл. 30,2 тис. га полезахисних лісових смуг; 115,5 тис. га інших категорій захисних насаджень; 17,9 тис. га не вкритих лісовою рослинністю земель; 11,9 тис. га інших лісових земель; 17,6 тис. га вкритих деревною та чагарниковою рослинністю земель.

Ліси та інші вкриті лісовою рослинністю землі становлять 355,9 тис. га, зокрема 308,5 тис. га вкриті лісом. Цікавою є інформація про площі лісів та інших вкритих лісовою рослинністю земель запасу та земель, не наданих у власність та постійне користування в межах населених пунктів станом на 01.01.2013 р., оскільки структура ландшафтів Донецького регіону є своєрідною. Близько 47 тис. га лісів є у межах населених пунктів, 25,4 тис. га лісових смуг 